This article was downloaded by: [Oregon Health \& Science University]

On: 3 November 2009

Access details: Access Details: [subscription number 907466074]

Publisher Routledge

Informa Ltd Registered in England and Wales Registered Number: 1072954 Registered office: Mortimer House, 37-41 Mortimer Street, London W1T 3JH, UK

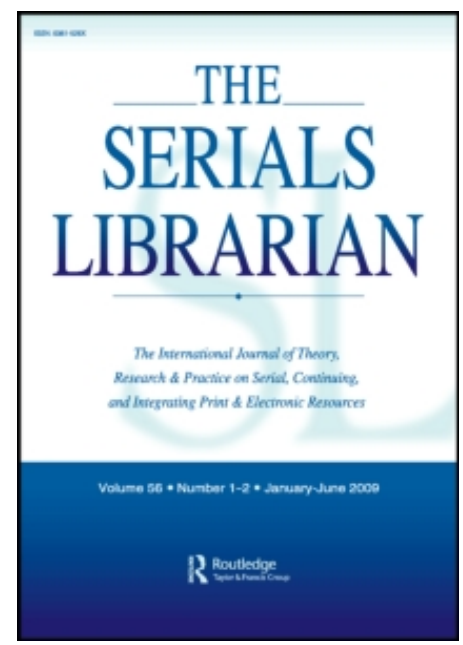

The Serials Librarian

Publication details, including instructions for authors and subscription information:

http://www.informaworld.com/smpp/title content=t792306962

\title{
The Bundling and Unbundling of E-Serials: Introduction
}

David Fowler a

a Knight Library, University of Oregon, Eugene, Oregon, USA

Online Publication Date: 01 November 2009

To cite this Article Fowler, David(2009)'The Bundling and Unbundling of E-Serials: Introduction',The Serials Librarian,57:4,350 — 352

To link to this Article: DOI: $10.1080 / 03615260903203694$

URL: http://dx.doi.org/10.1080/03615260903203694

\section{PLEASE SCROLL DOWN FOR ARTICLE}

\footnotetext{
Full terms and conditions of use: http://www.informaworld.com/terms-and-conditions-of-access.pdf

This article may be used for research, teaching and private study purposes. Any substantial or systematic reproduction, re-distribution, re-selling, loan or sub-licensing, systematic supply or distribution in any form to anyone is expressly forbidden.

The publisher does not give any warranty express or implied or make any representation that the contents will be complete or accurate or up to date. The accuracy of any instructions, formulae and drug doses should be independently verified with primary sources. The publisher shall not be liable for any loss, actions, claims, proceedings, demand or costs or damages whatsoever or howsoever caused arising directly or indirectly in connection with or arising out of the use of this material.
} 


\title{
THE BUNDLING AND UNBUNDLING OF E-SERIALS Edited by David Fowler
}

\section{The Bundling and Unbundling of E-Serials: Introduction}

\author{
DAVID FOWLER \\ Knight Library, University of Oregon, Eugene, Oregon, USA
}

When this collection of articles was originally conceived two years ago, it was already apparent that the days of the "Big Deal" were numbered and were likely coming to a close sometime in the foreseeable future. Library budgets around the world were (and continue to be) overstretched, overworked, and under-funded. Budget increases generally were failing to keep pace with inflation. Some institutions were receiving minimal funding to cover inflationary costs, while others were receiving none at all, creating an inevitable collision of the forces of vendor price increases and lack of library dollars. Those collisions have been occurring at an increasing speed, causing institutions, even financially sound institutions, to make hard collection development choices and to cancel journals at an ever-quickening rate. Institutions that once were involved in cancellation projects every ten years and later every five years are now cancelling titles every two years. Some are engaged in a permanent and ongoing cancellation process, re-evaluating and canceling titles every year.

All of this was occurring even before the world financial crisis hit libraries (and everyone else on the planet) beginning in late 2008. Libraries of all types are now in an even more acute financial situation than was imaginable one year previous. Public university libraries, particularly in the western United States, have been slashing budgets at a disturbing pace. Private institution libraries have been a little healthier, but not by a lot as endowments have sunk deeply, even going underwater in many cases. Large private libraries that had rarely seen a budget cut in their entire existence are doing so now. Serials budgets are being cut anywhere from three

Address correspondence to David Fowler, Head of Acquisitions, Knight Library, 1299 University of Oregon, Eugene, OR 97403, USA. E-mail: dcfowler@uoregon.edu 
to thirty percent on average. Monographs budgets have often been cut by a quarter or more. Many institutions cannot afford to buy any books at all.

The end result of all this financial turmoil is that the Big Deals entered into by libraries and consortia in the late 1990s and early 2000s, for which libraries paid a set premium above their print subscription charges in exchange for access to all or nearly all of a vendor's or publisher's journals, are no longer so beneficial for the majority of libraries. While it was true that these often provided great value in the early days, especially to smaller schools that suddenly could offer access to a huge number of journals they otherwise could not afford, the never-ending slog of eight- to ten-percent annual serials inflation has finally outstripped the ability of many if not most institutions to pay for these deals. The recent fiscal crisis has only exacerbated this situation, accelerating it and putting an exclamation point on it.

Some libraries are now having to divest themselves of most or all of their Big Deals. Sometimes this means that institutions will break their deals or not renew them when they expire. In this scenario, libraries examine their titles lists, including subscribed, shared, and sometimes pay-per-view titles, evaluate usage statistics and faculty citation and publishing numbers, and then decide to which individual titles they should continue to provide access.

Or a less drastic correction may be attempted, with the publisher and library working together to craft one or more smaller, affordable packages that could be built around broad or discrete subjects areas. This would also in part address another frequently voiced complaint about Big Deals: the homogenization of journals and journal packages across libraries, so that almost everyone ends up having the same content as everyone else. The break-up of these packages could return the library subject specialists/selectors to something resembling their previous level of influence, where they were able to completely craft their journal collections specifically toward their target audiences.

These, then, are the circumstances in which libraries find themselves in 2009. They are unenviable, but also unavoidable. How libraries will approach the crisis and proceed with ending their Big Deals is the focus of this special section of The Serials Librarian. While some of the five papers contained herein were written before the onset of the fiscal crisis and some after, they all still hold relevance as we and our peers struggle through this rough transition period.

Rickey Best of Auburn University opens the conversation by examining whether or not the Big Deal is truly dead or dying and why some institutions may be reluctant to give them up immediately.

Colleen Cleary of the Queensland University of Technology then looks at the reasons that the Big Deal has stuck around as long as it has and examines both the advantages and disadvantages it has brought to libraries. She also looks at the initial efforts at her institution to begin considering unbundling these packages. 
Next, Amy Carlson of the University of Hawai'i-Manoa and Barbara Pope of Pittsburg State University address how we as a community have been responding to the budget problems brought on or exacerbated by the Big Deal, and what the alternatives are in the publishing world to signing on to these large, cumbersome arrangements.

Louise Cole of Kingston University looks at the vital component of how to promote and make Big Deals accessible and visible to the end users and how Electronic Resources Management modules are being used to help with this effort.

Last, Christina Torbert of Ole Miss takes a slightly different spin, examining how purchases of journal backfile packages influence a library's budget and collection development efforts. She also shares the results of a survey she conducted regarding the factors libraries consider when purchasing these packages.

The next twelve months to two years will be critical to the future of libraries as they look for new ways to acquire and present materials in a time of declining budgets, but with an ever-demanding user base. Full or partial divestment of Big Deal packages is an inevitable element of this transition. The full impact of how libraries will cope is yet to be known, but it seems inevitable that the publishing landscape will look much different in 2011 and beyond than it does in 2009. 